INTERNATIONAL RESEARCH JOURNAL OF PHARMACY

www.irjponline.com

ISSN $2230-8407$

Research Article

\title{
ANTICANCER POTENTIAL OF METHANOLIC AND AQUEOUS EXTRACT OF LEUCAS INDICA (LINN.) AGAINST EHRLICH ASCITES CARCINOMA CELLS ON SWISS ALBINO MICE
}

Sarkar Mahananda ${ }^{1,2}$, Das Mousumi², Mitra Debmalya ${ }^{2}$, Jena Aditya Kumar ${ }^{2}$, De Arnab ${ }^{2}$, Samanta Amalesh ${ }^{2 *}$

${ }^{1}$ Department of Pharmacology, Institute of Pharmacy, Jalpaiguri, West Bengal, India

${ }^{2}$ Division of Microbiology, Department of Pharmaceutical Technology, Jadavpur University, Kolkata, India

*Corresponding Author Email: asamanta61@yahoo.co.in

Article Received on: 18/03/13 Revised on: 01/04/13 Approved for publication: 21/05/13

DOI: $10.7897 / 2230-8407.04641$

IRJP is an official publication of Moksha Publishing House. Website: www.mokshaph.com

(C) All rights reserved.

\section{ABSTRACT}

The present study was designed to evaluate the in vivo anticancer activity of methanolic and aqueous extract of Leucas indica Linn. (Aerial parts) against Ehrlich's Ascites Carcinoma (EAC) on Swiss albino mice. The anticancer activity was done by intra peritoneal transplantation of EAC cells into mice and subsequently analysis of ascitic fluid, haematological, biochemical and histopathological parameters along with body weight and percentage of life span. The animals were treated with the extracts at the dose level of 200 and $400 \mathrm{mg} / \mathrm{kg}$, intra peritoneally and compared to the reference drug vinblastine. Both the extracts showed significant dose dependent reduction of viable cells (cancer cells), increased non-viable cells (dead cells), decreased in body weight and increased the duration of life span. In case of hematological study the extracts showed increased hemoglobin level and RBC count but decreased WBC count. The certain important serum enzymes like glutamate oxaloacetate transaminase, glutamate pyruvate transaminase and alkaline phosphatase levels were also decreased in treated group of animals. Finally, in case of histopathological investigation of livers showed a significant protection and regeneration of EAC induced oxidative stress and cellular damage. The preliminary phytochemical screening of the extracts revealed the presence of flavonoids, total phenolic compounds, saponin and tannin. However the aqueous fraction of the Leucas indica possesses more potential anticancer property compared to methanolic fraction. The anticancer property of this plant was considered due to the presence of flavonoids and total phenolic compounds.

Keywords: Leucas indica, Methanolic extract, Aqueous extract, Anticancer, EAC cell, Vinblastine.

\section{INTRODUCTION}

Cancer is the second life threatening disease next to cardiovascular disorders, characterized by uncontrollable cellular growth, local tissue invasion and distance metastasis and cause more than 6million deaths per year and may increase up to 11.5 millions in the year of 2030 world wide ${ }^{1,2}$. To combat this so far mortal disease currently there are mainly three types of modern treatment like chemotherapy, radiotherapy and surgical procedure are available. Most of the chemotherapeutic agents cause severe toxicity on bone marrow cell, epithelial tissue, reticuloendothelial system, gonads etc. due to their high potency and low therapeutic index ${ }^{3}$. Hence, there is a major growing interest in current pharmacological research in Indian traditional system of medicine (natural origin) to develop new safest and efficient anticancer molecules to minimize the toxic effects of the existing medications ${ }^{4,5}$. Even the World Health Organization (WHO) and Food and Drug Administration (FDA) suggest the use of herbal medication as a complementary and alternative medicine for treatment of cancer and chemoprevention in human ${ }^{6,7}$. The several phytochemical agents like flavonoids, terpenoids, steroids etc have been taken as a great interest in drug design due to their multifunctional pharmacological activities including anticancer property ${ }^{8}$. The plant Leucas indica Linn. (Family: Labiatae) is commonly known as 'Dandokalos' in Bengali. It is distributed almost in every state of India but abundantly present in 'Mahananda Neora Valley' in West Bengal. It is an erect herb with pubescent branching. The leaves of this plant are linear-lanceolate in nature while the flowers are white with four stamens ${ }^{9}$. Traditionally, the leaves of this plant are used as vermifuge, stomachic, sedative and in sores ${ }^{10}$. The methanolic fraction of this plant showed significant wound healing activity ${ }^{11}$. The aqueous and methanolic extract of the aerial parts of Leucas indica having significant hypoglycemic, anti-inflammatory and antioxidant activity $^{12,13}$. However, based on the literature survey and the lack of any research activities in anticancer field on this plant, the present study was designed to evaluate the anticancer potential by taking crude extracts of Leucas indica on EAC induced mice.

\section{MATERIALS AND METHODS \\ Plant material}

The aerial parts of Leucas indica Linn. were collected in August, 2011 from Duars region, Jalpaiguri District, West Bengal, India. It was identified and authenticated from Central National Herbarium, Botanical Survey of India, Howrah-711103, West Bengal (Vide No. CNH/32/2012/ Tech.II/625 Dated: 06.03.2012). After proper washing, it was dried under shade at a room temperature for seven days and then grinded with a mechanical grinder. Finally, the coarse powders were separated by sieving using 40 mesh apertures and stored in an air tight container for further use.

\section{Preparation of plant extract}

The fresh coarse powders were subjected to maceration by petroleum ether to remove fatty materials and then successively extracted with chloroform, ethyl acetate, methanol and distilled water according to ascending order of polarity of solvent using a Soxhlet apparatus. The each fraction of the extract was then filtered and concentrated to dryness in a rotary vacuum evaporator under reduced pressure and temperature and stored in desiccators. During performing the experiment, the dried methanloic and aqueous extract of Leucas indica were dissolved in distilled water to prepare the subsequent doses of extract (LIME and LIAE).

\section{Chemicals and reagents}

Trypan blue, methyl violet, sodium sulphate, methylene blue, sodium chloride, propylene glycol were purchased from MERCK Pvt. Ltd. (Mumbai, India) and Vinblastine Sulphate 
from Cipla Pvt. Ltd. (Goa, India). The reagent kit for the measurement of serum glutamate oxaloacetate transaminase, glutamate pyruvate transaminase and alkaline phosphatase is from SPAN Diagnostic Pvt. Ltd (Mumbai, India). The remaining solvents and chemicals were used for this studies are in analytical grade.

\section{Experimental Animals}

Swiss albino mice (weighing 20-25 g) of either sex were used to perform the present study. The animals were randomly grouped $(n=6)$ and housed in polyacrylic cages $(38 \times 23 \times 10$ $\mathrm{cm})$ and maintained under standard laboratory conditions (Temp. $25 \pm 2^{\circ} \mathrm{C}$ ) with dark and light cycle $(14 / 10 \mathrm{~h})$. They were allowed to free access of standard dry pellet diet (Hindustan Lever, Kolkata, India) and water ad libitum. The animals were acclimatized to laboratory condition for 1 week before commencement of this experiment. The ethical clearance was obtained from Jadavpur University Animal Ethical Committee for using animals in the present study (Vide No. 0367/01/C/CPCSEA, India).

\section{Phytochemical screening}

The preliminary phytochemical screening of LIME and LIAE were done by the standard method mentioned by Trease and Harbone ${ }^{14,15}$.

\section{Acute toxicity study}

The acute toxicity study was done by Litchfield and Hilaly methods with some necessary modifications ${ }^{16,17}$. The animals of either sex were divided into several groups containing 10 animals of each. Different doses of aqueous fraction (200, $500,1000,1500,2000,2500,3000,3500,4000$ and 4500 $\mathrm{mg} / \mathrm{kg})$ and methanolic fraction $(200,500,1000,1500,2000$, $2500,3000,3500 \mathrm{mg} / \mathrm{kg}$ ) were administered orally (single dose) to the treated groups but control groups received only normal saline orally $(5 \mathrm{ml} / \mathrm{kg})$ under overnight fasting condition. The sign of toxicity and mortality were recorded within $24-72 \mathrm{~h}$ for all groups of animals. The $\mathrm{LD}_{50}$ was determined using graphical representation using probit analysis.

\section{In vivo anticancer activity \\ Transplantation of cancer cells}

The EAC cells were collected from the Chittaranjan National Cancer Institute (CNCI), Kolkata, India and maintained in in vivo in Swiss albino mice by serial intra peritoneal transplantation about $2 \times 10^{6}$ cells/mouse for every 10 days. The ascitic fluid was drawn out from the EAC implanted mice at the $\log$ phase (days $7^{\text {th }}$ ) and prepared a suspension in phosphate buffer ( $\mathrm{pH}$ 7.2-7.4). All the experimental animals (except control group) received about $0.1 \mathrm{ml}$ of ascitic fluid suspension (i.p) containing $2 \times 10^{6}$ cancer cells and it was considered as day ' 0 '.

\section{Experimental design}

The animals were divided into seven groups of six animals in each. Group-I served as negative or normal control (normal saline, $5 \mathrm{ml} / \mathrm{kg}$, i.p). Group II was denoted by positive or EAC control. Group-III, IV, V and VI served as LIME (200 and $400 \mathrm{mg} / \mathrm{kg}$, i.p) and LIAE (200 and $400 \mathrm{mg} / \mathrm{kg}$, i.p) treated group respectively. Group-VII was designed as reference group (vinblastine $1 \mathrm{mg} / \mathrm{kg}$, i.p). After $24 \mathrm{~h}$ of cancer cells implantation, all the animals were administered the respective dose by intra peritoneal injection on daily for nine consecutive days. The half of the animals in each group was sacrificed on day $10^{\text {th }}$ by cervical dislocation after overnight fasting condition. The intra peritoneal fluid was collected from each sacrificed animal to measure ascitic fluid volume, packed cell volume, viable cells (cancer cells) count and non-viable cells (dead cells) count. The blood sample was collected directly from the heart of the sacrificed animals to analysis haematological and biological parameters. The remaining half of the animals in each group was kept with normal diet and water ad libitum to record mean survival time and percentage increase life $\operatorname{span}^{18}$.

\section{Estimation of ascetic and packed cells volume}

The ascitic fluid was collected from peritoneal cavity using graduated centrifuge tube and measured directly the ascetic cells volume. The collected ascetic fluid was then subjected to centrifugation (REMI RM-12C, India) at $1000 \mathrm{rpm}$ for five minutes and measured packed cell volume in sedimentation form ${ }^{18}$.

\section{Estimation of viable and non-viable cells count}

The ascitic fluid was taken in a WBC pipette and diluted to 100times. The cells were then stained by trypan blue dye and placed in a Neubauer Hemocytometer (MARIE field, Germany). The non-viable cells took the stain whereas the viable cells remained transparent and counting was done accordingly ${ }^{18}$. Here,

$$
\begin{gathered}
\text { Cell count }=(\text { Number of cells } \times \text { dilution factor }) / \\
(\text { Area } \times \text { thickness of liquid film })
\end{gathered}
$$

\section{Estimation of haemoglobin}

The blood sample was collected by direct puncturing of heart and mixed with heparin to prevent coagulation. About $20 \mu 1$ of heparinized blood was transferred in Sahli's Haemoglobinometer and diluted with $0.1(\mathrm{~N}) \mathrm{HCl}$ till the matching of color with the standard one. The reading was taken directly from graduated tube ${ }^{19}$.

\section{Estimation of RBC count}

The blood sample was diluted to 100 times with RBC diluting fluid using Thoma pipette and mixed well accordingly. About one drop resultant mixed solution was placed in Neubauer Haemocytometer and allowed to settlement of RBC for three minutes followed by counting was done in 80 small squares under microscope $\mathrm{e}^{20}$.

\section{Estimation of WBC count}

The blood sample was diluted to 20 times with WBC diluting fluid using Thoma pipette and mixed well. About one drop resultant solution was placed in Neubauer Haemocytometer and allowed to settlement of WBC for 3 minutes followed by counting was done under microscope in 4 large corner blocks that was further divided into 64 small squares ${ }^{20}$.

\section{Measurement of biochemical parameters}

The collected blood samples were subjected to centrifuge to separate serum. The serum was then subjected to spectroscopic analysis to determine the serum biochemical parameters, such as glutamate oxaloacetate transaminase (SGOT), glutamate pyruvate transaminase (SGPT) and serum alkaline phosphatase (SALP) by using automated diagnostic reagent $\mathrm{kit}^{21}$. 
Estimation of body weight, survival time and increase life span

The change in body weight $(\mathrm{gm})$ was recorded on day $10^{\text {th }}$ of the experimental period. The survival times of remaining half of the experimental animals ware noted from beginning of the study to till death or up to maximum 6 weeks and the percentage increase life span was calculated using following formula ${ }^{22}$ :

Percentage increase life span $(\%$ ILS $)=$ [(Mean survival time of treated group/ Mean survival time of control group) -1$] \times 100$, Where the mean survival time (days) $=$ (days of first death + days of last death) $/ 2$

\section{Histopathological Study}

Finally, the tissues of liver were dissect out from each group of sacrificed animal on $10^{\text {th }}$ day and preserved immediately in formalin solution. The harvested tissues were then subjected to very thin section by using microtome instrument and fixed in $10 \%$ neutral formalin solution, embedded in paraffin, stained with hematoxylin $(\mathrm{H})$ and eosin (E) and finally photographs were taken by digital camera and binocular microscope.

\section{Statistical analysis}

The results were expressed as mean \pm SEM. Statistical differences between the treated and control groups were determined by one way ANOVA followed by Dunnet's test using the computer software, Prism graph pad version 5. The ' $p$ ' values less than 0.05 was considered as statistically significant.

Table 1: Effect of LIME \& LIAE on Ascitic Fluid Parameters

\begin{tabular}{|c|c|c|c|c|}
\hline Group & Ascitic fluid volume (ml) & Packed cells volume (ml) & Viable cells count $/ \mathrm{ml} \times 10^{7}$ & Non-viable cells count $/ \mathrm{ml} \times 10^{7}$ \\
\hline EAC control & $3.37 \pm 0.13$ & $1.64 \pm 0.12$ & $6.83 \pm 0.44$ & $0.51 \pm 0.10$ \\
\hline LIME $200 \mathrm{mg} / \mathrm{kg}$ & $3.09 \pm 0.11^{\mathrm{ns}}$ & $1.43 \pm 0.12^{\mathrm{ns}}$ & $6.01 \pm 0.09^{\mathrm{a}}$ & $0.86 \pm 0.04^{\mathrm{ns}}$ \\
\hline LIME $400 \mathrm{mg} / \mathrm{kg}$ & $2.81 \pm 0.09^{\mathrm{a}}$ & $1.21 \pm 0.07^{\mathrm{b}}$ & $5.66 \pm 0.09^{b}$ & $1.07 \pm 0.04^{\mathrm{c}}$ \\
\hline LIAE $200 \mathrm{mg} / \mathrm{kg}$ & $2.67 \pm 0.26^{\mathrm{b}}$ & $0.74 \pm 0.05^{\mathrm{c}}$ & $3.72 \pm 0.15^{\mathrm{c}}$ & $1.93 \pm 0.12^{\mathrm{c}}$ \\
\hline LIAE $400 \mathrm{mg} / \mathrm{kg}$ & $1.70 \pm 0.11^{\mathrm{c}}$ & $0.37 \pm 0.02^{\mathrm{c}}$ & $2.25 \pm 0.26^{\mathrm{c}}$ & $2.33 \pm 0.10^{\mathrm{c}}$ \\
\hline Vinblastine $1 \mathrm{mg} / \mathrm{kg}$ & $0.84 \pm 0.02^{\mathrm{c}}$ & $0.25 \pm 0.02^{\mathrm{c}}$ & $1.75 \pm 0.14^{\mathrm{c}}$ & $2.69 \pm 0.22^{\mathrm{c}}$ \\
\hline
\end{tabular}

Values are expressed as Mean \pm SEM; $n=6$; Where, ns: not significant; ${ }^{a} \mathrm{p}<0.05 ;{ }^{b} \mathrm{p}<0.01 ;{ }^{\mathrm{c}} \mathrm{p}<0.001$.

LIME: Leucas indica methanolic extract; LIAE: Leucas indica aqueous extract.

Table 2: Effect of LIME \& LIAE on Haematological Parameters

\begin{tabular}{|c|c|c|c|}
\hline Group & Haemoglobin $(\mathbf{g} / \mathbf{d l})$ & RBC count (million/ $\boldsymbol{\mu l})$ & WBC count (thousand/ $\boldsymbol{\mu l})$ \\
\hline Normal control & $11.52 \pm 0.36$ & $4.05 \pm 0.22$ & $3.97 \pm 0.19$ \\
\hline EAC control & $5.45 \pm 0.23$ & $2.75 \pm 0.21$ & $5.30 \pm 0.28$ \\
\hline LIME $200 \mathrm{mg} / \mathrm{kg}$ & $5.82 \pm 0.08^{\mathrm{ns}}$ & $2.88 \pm 0.05^{\mathrm{ns}}$ & $5.15 \pm 0.04^{\mathrm{ns}}$ \\
\hline LIME $400 \mathrm{mg} / \mathrm{kg}$ & $6.92 \pm 0.06^{\mathrm{b}}$ & $3.11 \pm 0.02^{\mathrm{a}}$ & $4.14 \pm 0.03^{\mathrm{b}}$ \\
\hline LIAE $200 \mathrm{mg} / \mathrm{kg}$ & $7.95 \pm 0.20^{\mathrm{c}}$ & $3.28 \pm 0.04^{\mathrm{b}}$ & $4.37 \pm 0.26^{\mathrm{a}}$ \\
\hline LIAE 400mg/kg & $9.91 \pm 0.37^{\mathrm{c}}$ & $3.53 \pm 0.03^{\mathrm{c}}$ & $4.26 \pm 0.36^{\mathrm{a}}$ \\
\hline Vinblastine $1 \mathrm{mg} / \mathrm{kg}$ & $10.12 \pm 0.39^{\mathrm{c}}$ & $3.87 \pm 0.07^{\mathrm{c}}$ & $4.07 \pm 0.13^{\mathrm{b}}$ \\
\hline
\end{tabular}

Values are expressed as Mean \pm SEM; $n=6$; Where, ns: not significant; ${ }^{a} \mathrm{p}<0.05 ;{ }^{\mathrm{b}} \mathrm{p}<0.01 ;{ }^{\mathrm{c}} \mathrm{p}<0.001$.

LIME: Leucas indica methanolic extract; LIAE: Leucas indica aqueous extract.

Table 3: Effect of LIME \& LIAE on Serum Biochemical Parameters

\begin{tabular}{|c|c|c|c|}
\hline Group & SGOT (IU/L) & SGPT (IU/L) & SALP (KA units/dI) \\
\hline Normal control & $32.61 \pm 1.35$ & $15.81 \pm 1.14$ & $6.40 \pm 0.52$ \\
\hline EAC control & $73.57 \pm 2.24$ & $60.56 \pm 2.05$ & $21.41 \pm 1.18$ \\
\hline LIME $200 \mathrm{mg} / \mathrm{kg}$ & $71.54 \pm 1.92^{\text {ns }}$ & $57.08 \pm 1.31^{\text {ns }}$ & $20.90 \pm 0.99^{\text {ns }}$ \\
\hline LIME $400 \mathrm{mg} / \mathrm{kg}$ & $68.08 \pm 1.47^{\mathrm{a}}$ & $52.36 \pm 1.32^{\mathrm{b}}$ & $18.43 \pm 0.58^{\mathrm{a}}$ \\
\hline LIAE $200 \mathrm{mg} / \mathrm{kg}$ & $52.08 \pm 1.50^{\mathrm{c}}$ & $45.05 \pm 1.96^{\mathrm{c}}$ & $12.10 \pm 0.33^{\mathrm{c}}$ \\
\hline LIAE $400 \mathrm{mg} / \mathrm{kg}$ & $44.17 \pm 1.46^{\mathrm{c}}$ & $32.43 \pm 0.63^{\mathrm{c}}$ & $8.37 \pm 0.54^{\mathrm{c}}$ \\
\hline Vinblastine $1 \mathrm{mg} / \mathrm{kg}$ & $37.56 \pm 1.44^{\mathrm{c}}$ & $22.48 \pm 1.28^{\mathrm{c}}$ & $7.14 \pm 0.31^{\mathrm{c}}$ \\
\hline
\end{tabular}

Values are expressed as Mean \pm SEM; $n=6$; Where, ns: not significant; ${ }^{\mathrm{a}} \mathrm{p}<0.05 ;{ }^{\mathrm{b}} \mathrm{p}<0.01 ;{ }^{\mathrm{c}} \mathrm{p}<0.001$.

LIME: Leucas indica methanolic extract; LIAE: Leucas indica aqueous extract; SGOT: Serum glutamate oxaloacetate transaminase; SGPT: Serum glutamate pyruvate transaminase; SALP: Serum alkaline phosphatase.

Table 4: Effect of LIME \& LIAE on Body Weight, Survival Time and Life Span

\begin{tabular}{|c|c|c|c|}
\hline Group & BW (gm) & MST (day) & \% ILS \\
\hline Normal control & $1.26 \pm 0.04$ & - & - \\
\hline EAC control & $15.04 \pm 0.24$ & $17.67 \pm 0.42$ & - \\
\hline LIME $200 \mathrm{mg} / \mathrm{kg}$ & $13.96 \pm 0.14^{\mathrm{a}}$ & $20.00 \pm 0.58^{\mathrm{a}}$ & 13.19 \\
\hline LIME $400 \mathrm{mg} / \mathrm{kg}$ & $12.87 \pm 0.14^{\mathrm{b}}$ & $24.17 \pm 0.31^{\mathrm{b}}$ & 36.79 \\
\hline LIAE $200 \mathrm{mg} / \mathrm{kg}$ & $6.84 \pm 0.32^{\mathrm{c}}$ & $28.67 \pm 0.49^{\mathrm{c}}$ & 62.25 \\
\hline LIAE $400 \mathrm{mg} / \mathrm{kg}$ & $5.93 \pm 0.31^{\mathrm{c}}$ & $31.67 \pm 1.34^{\mathrm{c}}$ & 79.23 \\
\hline Vinblastine $1 \mathrm{mg} / \mathrm{kg}$ & $4.17 \pm 0.09^{\mathrm{c}}$ & $34.00 \pm 1.07^{\mathrm{c}}$ & 92.41 \\
\hline
\end{tabular}

Values are expressed as Mean \pm SEM; $n=6$; Where, ns: not significant; ${ }^{a} \mathrm{p}<0.05 ;{ }^{b} \mathrm{p}<0.01 ;{ }^{\mathrm{c}} \mathrm{p}<0.001$.

LIME: Leucas indica methanolic extract; LIAE: Leucas indica aqueous extract; BW: Body weight; MST: Mean survival time; ILS: Increase life span. 

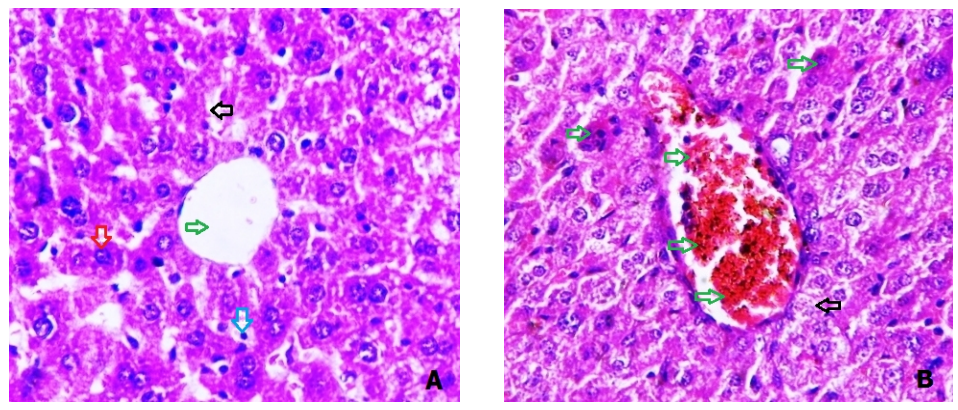

Figure 1A: Normal control liver section showing clear lobular structure, normal central vein (green arrow), hepatocytes with distinct nucleus (red arrow), clear sinusoids (black arrow) and distinct kuffer's cells (blue arrow). Figure 1B: EAC control liver section showing enough inflammatory regions (green arrow) and fibrotic change (black arrow) in central vein and entire section. Microscopically Photograph $(\mathrm{H}$ and $\mathrm{E} \times 10)$
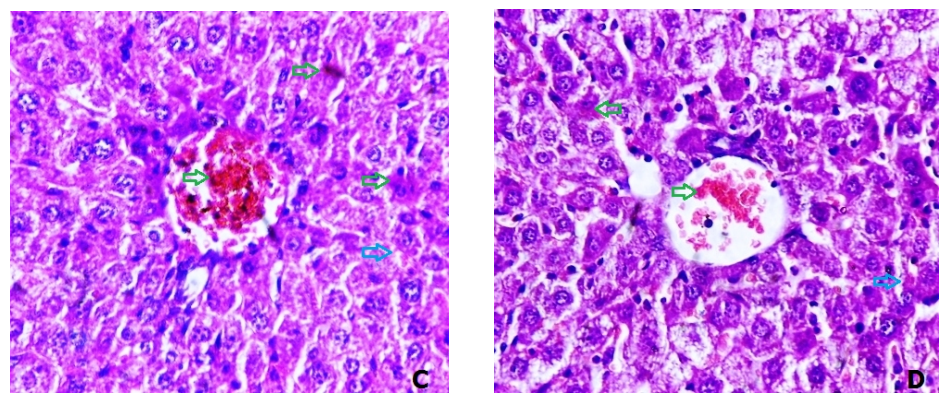

Figure 1C: LIME $200 \mathrm{mg} / \mathrm{kg}$ treated liver section showing comparatively less inflammable area than EAC control (green arrow) and less fibrotic change (blue arrow). Figure 1D: LIME $400 \mathrm{mg} / \mathrm{kg}$ treated liver section showing comparatively less inflammable area than LIME $200 \mathrm{mg} / \mathrm{kg}$ (green arrow) and less fibrotic change (blue arrow). Microscopically Photograph ( $\mathrm{H}$ and $\mathrm{E} \times 10$ )
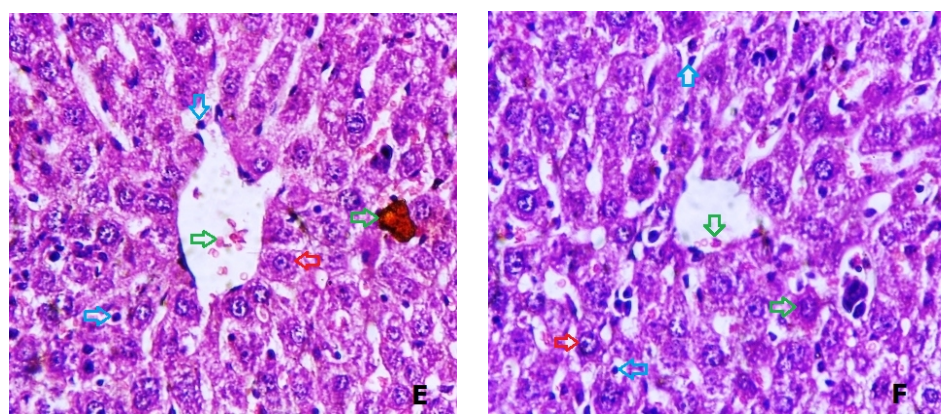

Figure 1E: LIAE $200 \mathrm{mg} / \mathrm{kg}$ treated liver section showing comparatively less inflammable area than LIME treated group (green arrow) and no fibrotic change, distinct kuffer's cells (blue arrow) and hepatic cells (red arrow). Figure 1F: LIAE $400 \mathrm{mg} / \mathrm{kg}$ treated liver section showing very little inflammable area (green arrow), kuffer's cells (blue arrow) and hepatic cells (red arrow) are normal. Microscopically Photograph (H and $\mathbf{E} \times 10)$

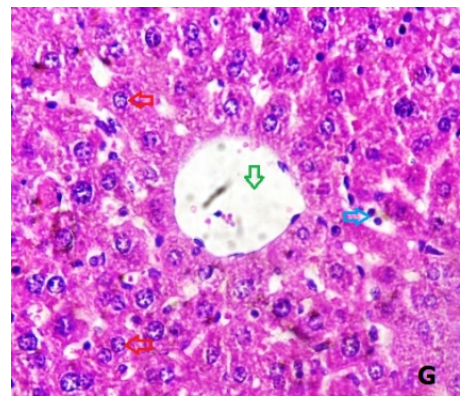

Figure 1G: Vinblastine 1mg/kg treated liver section showing non-inflammable area with normal central vein (green arrow), hepatocytes (red arrow) and Kuffer's cells (blue arrow). Microscopically Photograph $(\mathrm{H}$ and $\mathrm{E} \times 10)$ 


\section{RESULTS}

\section{Phytochemical screening}

The preliminary phytochemical screening of LIME and LIAE confirmed the presence of flavonoids, total phenolic compounds, saponin and tannin.

\section{Acute toxicity study}

In case of acute toxicity study the measured $\mathrm{LD}_{50}$ values were 1995 and $2630 \mathrm{mg} / \mathrm{kg}$ for the methanolic and aqueous extract respectively. However no mortality was found up to 1000 $\mathrm{mg} / \mathrm{kg}$ for aqueous extract and up to $500 \mathrm{mg} / \mathrm{kg}$ for methanolic one.

\section{Ascitic fluid parameters}

Both the fraction LIME and LIAE showed significant dose dependent reduction of ascetic fluid volume, packed cell volume, viable cell count but increase non-viable cell count when compared to EAC control animals. The LIAE showed more potential action $(\mathrm{p}<0.01, \mathrm{p}<0.001)$ compared to LIME $(\mathrm{p}<0.05)$ but in lower dose of LIME $(200 \mathrm{mg} / \mathrm{kg})$ the results was insignificant except in viable cell count where it was significant $(\mathrm{p}<0.05)$. However the reference drug vinblastine showed more significant result compared to LIME and LIAE (Table 1).

\section{Haematological parameters}

There was remarkable reduction of haemoglobin level (5.45 \pm 0.23$)$ and RBC counts $(2.75 \pm 0.21)$ and increase WBC counts $(5.30 \pm 0.28)$ in EAC control group of animals during the experimental period. The aqueous fraction of this plant showed dose dependent increase in haemoglobin level nearer to normal value $(7.95 \pm 0.20$ and $9.91 \pm 0.37)$. The methanolic fraction $(400 \mathrm{mg} / \mathrm{kg})$ showed less significant result in respect of haemoglobin level $(6.92 \pm 0.06)$ whereas in lower dose $(200$ $\mathrm{mg} / \mathrm{kg}$ ) the result was insignificant. There was significant increase in RBC counts (3.28 \pm 0.04 and $3.53 \pm 0.03)$ and decreased in WBC counts $(4.37 \pm 0.26$ and $4.26 \pm 0.36)$ in LIAE treated group. In case of RBC and WBC counts the LIME $(400 \mathrm{mg} / \mathrm{kg})$ also showed significant results but in lower dose the results were insignificant (Table 2).

\section{Biochemical parameters}

There was extensive elevation of SGOT $(73 \pm 2.24)$, SGPT $(60 \pm 2.05)$ and SALP $(21 \pm 1.18)$ in EAC control animals. Both the fraction LIAE and LIME reduced the elevated serum enzymes level nearer to normal values. The results of LIAE (200 and $400 \mathrm{mg} / \mathrm{kg}$ ) treated groups were more significant than LIME $(400 \mathrm{mg} / \mathrm{kg})$ treated group. At lower dose of LIME $(200 \mathrm{mg} / \mathrm{kg}$ ) the results were insignificant again (Table 3).

\section{Body weight and survival time}

In case of EAC control animals there was a remarkable increase in body weight $(15.04 \pm 0.24)$ compared to normal control mice (1.26 \pm 0.04$)$. The aqueous fraction of this plant showed significant dose dependent reduction in body weight $(6.84 \pm 0.32$ and $5.93 \pm 0.31)$ and increased percentage life span $(62.25 \%$ and $79.23 \%)$. The results of LIME treated groups were less significant compared to LIAE treated groups again (Table 4).

\section{Histopathological observation}

The histopathological observation of livers section were found to enough distinguish between each group of animals. The normal control section showed clear lobular structure with normal central vein, hepatocytes, sinusoids and kuffer's cells and without any inflammable area in the entire section (Figure 1A). The EAC control section showed enough inflammatory regions in central vein, hepatocytes and sinusoids along with degenerative change in the lobular design (Figure 1B). The results of LIME treated groups showed comparatively less abnormality than EAC control group (Figure 1C and 1D). The LIAE (200 and $400 \mathrm{mg} / \mathrm{kg}$ ) treated sections showed very little inflammable regions and less abnormality compared to LIME treated group (Figure 1E and $1 \mathrm{~F}$ ). The reference drug vinblastine treated liver section showed almost normal lobular architecture along with noninflammable area and very less fibrotic change in entire section (Figure 1G).

\section{DISCUSSION}

The most valuable and dependable criteria for judging a potent anticancer agent are prolongation of life span, decrease in body weight and reduction of the leukocyte count of the host $^{23}$. The intra peritoneal transplantation of EAC cells induces a local inflammatory reaction causing intense vascular permeability, resulting progressive ascitic fluid formation and accumulation which is the main nutritional source for growing of the cancer cells ${ }^{24}$. It is reported that any type of carcinoma generate several reactive oxygen species (ROS) like super oxide anion $\left(\mathrm{O}_{2}{ }^{-}\right)$, hydroxyl radicals $\left(\mathrm{OH}^{+}\right)$, peroxyl radical (ROO.) etc. These highly toxic free radicals easily react with most of the biomolecules including protein, lipoprotein, enzymes, DNA and $\mathrm{RNA}^{25}$. In case of EAC induced carcinogenesis there was an extreme generation of peroxide radicals that bind with membrane protein causing remarkable destruction of erythrocyte cells and lowers the haemoglobin level. The leukocyte cells also try to compensate such free radical mediated oxidative stress by scavenging such toxic radicals. So in the present study there was an abrupt elevation of leukocyte count ${ }^{26}$. The certain endogenous biological agents like interferon, interleukins (cytokine), tumor necrosis factor etc provide nonspecific active immunity and showing cytotoxicty on malignant cells. These agents inhibit tumor growth by disturbing cellular proliferation, immunomodulation, impairment of angiogenesis and suppression of oncogene activation. The endogenous monoclonal antibodies also provide some passive immunity and destroy the cancer cells by expressing numbers of cell surface antigen molecules. It was observed in our present study that both the fraction LIME and LIAE inhibited tumor growth decreased the intra peritoneal fluid volume and increased the lifespan of EAC induced animals. They also decreased the viable cells (tumor cells) and increased the non-viable cells count towards normal level. It is well established that the natural product vinblastine (reference drug) inhibits tumor growth by impairing mitosis cell division due to suppression of microtubule formation and microtubule polymerization ${ }^{27,28}$. The flavonoids molecule like quercetin, kaemferol etc. are having chemopreventive role in cancer therapy by inhibiting intracellular signal transduction pathway, suppressing cellular proliferation and angiogenesis inhibition $^{29}$. The phenolic compounds exhibits anticancer potency by inhibiting the mitosis cell division at telophase stage and inhibit cellular protein synthesis resulting prevention of colony formation followed by restriction of tumor growth ${ }^{30}$. Both the fractions of Leucas indica herbs showed significant cytotoxicity on tumor cells as they contain reproducible quantity of flavonoids and phenolic compounds. They inhibited tumor growth by suppressing mitosis cell 
division (as like vinblastine) and reduced vascular permeability to inhibit nourishment of EAC cells. They also stimulated production of immunogenic cells like interleukins resulting destruction of tumor cells (as like endogenous molecules). The most of the modern anticancer chemotherapeutic agents causes severe adverse effect like bone marrow depression and anaemia ${ }^{31}$. In our present study the aqueous and methanolic fraction of the plant tried to restore the erythrocyte count and haemoglobin level nearer to normal value indicates protective action on the haemopoietic system as well as less toxicity on bone marrow cell. It is well known fact that, induction of EAC cell cause hepatotoxicity and subsequently increases the certain liver enzymes such as glutamate oxaloacetate transaminase, glutamate pyruvate transaminase and alkaline phosphatase remarkably ${ }^{32}$. The intra peritoneal administration of the LIAE and LIME prevented such type of EAC induced hepatotoxicity and restored the enzymes level nearer to normal level. The EAC induced carcinogenesis causes oxidative stress mediated inflammatory and degenerative change in liver as we observed in our histopathological study. Both the fraction of the plant tried to rectify such inflammatory and degenerative change in hepatic cells, central vein and sinusoids by scavenging the toxic free radicals. Finally, it can be concluded that the aqueous fraction of Leucas indica showed better results in each parameter probably by presence of more flavonoids and phenolic constituents in aqueous fraction compared to methanolic one. However further studies are recommended to isolate the pure compounds and to elucidate the specific mechanism of anticancer potential of the plant Leucas indica.

\section{ACKNOWLEDGEMENT}

The authors are thankful to the Scientist, Botanical Survey of India, Central National Herbarium, Botanical Garden, Howrah,West Bengal, India for identification and authentication of the plant species.

\section{REFERENCES}

1. Dashora N, Sodde V, Bhagat J, Kirti SP, Labo R. Antitumor activity of Dendrophoe falcate against Ehrlich Ascites Carcinoma in Swiss albino Mice. Pharmaceutical Crops 2011; 2: 1-7. http://dx.doi.org/ $10.2174 / 2210290601102010001$

2. Kathiriya A, Das K, Kumar EP, Mathai KB. Evaluation of Antitumor and Antioxidant Activity of Oxalis Corniculata Linn. against Ehrlich Ascites Carcinoma on Mice. Iran J Cancer Prev 2010; 4: 157-65.

3. Lasic DD. Doxorubicin in sterically stabilized liposomes. Nature 1996; 380: 561-562. http://dx.doi.org/10.1038/380561a0 PMid:8606781

4. Muneerudeen J, Himanshu J, Gururaja MP, Devi Swapna PV, Lekshmi $\mathrm{P}$, Jipnomon $\mathrm{J}$ et al. Anticancer potential of Bambusa bambos leaf extracts. Int Res J Pharm 2013; 4(4): 205-208.

5. Hemamalini K, Soujanya GL, Bhargav A, Vasireddy U. In vivo anticancer activity of Tabebuia rosa (Bertol) DC. Leaves on Dalton's ascetic lymphoma in mice. IJPSR 2012; 3(11): 4496-4502.

6. Kameshhwaran S, Suresh V, Arunachalam G, Kanthlal SK, Mohanraj M. In vitro and in vivo anticancer activity of methanolic extract of Tecoma stans flowers. IRJP 2012; 3(3): 246-251.

7. Chinnasamy A, Subramanian VS, Gajendran B. Anticancer activity of Pongamia glabra V. seed oil extract against selected human cancer cell lines. IRJP 2012; 3(8): 131-134.

8. Gupta M, Mazumder UK, Kumar RS, Kumar TS. Antitumor activity and antioxidant role of Bauhinia racemosa against Ehrlich ascites carcinoma in swiss albino mice. Acta Pharmacol Sin 2004; 25(8): 1070-1076. PMid: 15301742

9. Ramalingam R, Hima Bindu K, Bindu Madhavi B, Ravinder Nath A, David B. Pharmacognostical, Phytochemical and Anthelmintic Evaluation of Leucas indica (L). Pharmacognosy Journal 2009; 2(10): 317-323. http://dx.doi.org/10.1016/S0975-3575(10)80102-6

10. Madhava Chetty K, Sivaji K, Tulasirao K. Flowering plants of Chittor District, Andhra Pradesh. Tirupati, India. Students offset printers; 2008. p. 277
11. Saha K, Mukharjee PK, Das J, Pal M, Saha BP. Wound healing activity of Leucas indica Ress. J Ethanopharmacolgy 1997; 56(2): 139-44. http://dx.doi.org/10.1016/S0378-8741(97)01522-5

12. Sarkar M, Biswas P, Samanta A. Study of Hypoglycemic Activity of Aqueous Extract of Leucas indica Linn. Aerial Parts on Streptozotocin Induced Diabetic Rats. IJPSDR 2013; 5(2): 50-55.

13. Sarkar M, Biswas $\mathrm{P}$, Samanta A. In vivo anti-inflammatory and in vitro antioxidant studies on methanolic and aqueous extract of Leucas indica L. Asian J Pharm Clin Res 2013; 6(Suppl 2): 284-290.

14. Trease GE, Evans WC. Pharmacology, $15^{\text {th }}$ ed, London. Saunders Publishers; 2002, p. 42-44, 221-229, 246-249, 303-306, 331-332, 391393.

15. Harborne JB. Phytochemistry. London: Academic Press; 1993. p. 89131

16. Litchfield JT, Wilcoxon F. A simplified method of evaluating doseeffect experiments. J Pharmacol Exp Ther 1949; 96: 99-133. PMid: 18152921

17. Hilaly JE, Israili ZH, Lyoussi B. Acute and chronic toxicological studies of Ajuga iva in experimental animals. J Ethnopharmacol 2004; 91: 4350. http://dx.doi.org/10.1016/j.jep.2003.11.009 PMid:15036466

18. Lalee A, Pal P, Bhattacharya B, Samanta A. Evaluation of Anticancer activity of Aerva sanguinolenta (L.) (Amaranthaceae) on Ehrlich Ascites cell induced Swiss Mice. Int J Drug Dev \& Res 2012; 4(1): 203-209.

19. Sood R. Medical laboratory technology. $5^{\text {th }}$ ed. Jaypee Brothers Medical Publishers: India; 1999. p. 173-174

20. D'armour FE, Blood FR, Belden DA. The manual for laboratory work in mammalian physiology. $3^{\text {rd }}$ ed. Chicago: University of Chicago Press; 1965. p. 4-6

21. Kind PRN, King EJ. Estimation of plasma phosphatase by determination of hydrolysed phenol with antipyrin. J Clin Pathol 1954; 7: 322-331. http://dx.doi.org/10.1136/jcp.7.4.322 PMid:13286 357 PMCid:1023845

22. Bala A, Kar B, Haldar PK, Majumder UK, Bera S. Evaluation of anticancer activity of Cleome gynandra on Ehrlich's Ascites Carcinoma treated mice. J Ethnopharmacology 2010; 129(1): 131-134. http://dx.doi.org/10.1016/j.jep.2010.03.010 PMid:20307641

23. Oberling C, Guerin M. The role of viruses in the production of cancer. Advances in Cancer Research 1954; 2: 353-423. http:/ /dx.doi.org/10.1016/S0065-230X(08)60499-6

24. Dahanukar SA, Kulkarni RA, Rege NN. Pharmacology of medicinal plants and natural products. Indian J Pharmacol 2000; 32: 581-5.

25. Roy S, Dutta Choudhury M, Paul SB. Antioxidant potential of rhizome of Alocasia decipiens schott. Asian J Pharm Clin Res 2013; 6(2): 120122 .

26. Chatterjee D, Sahu RK, Jha AK, Dwivedi J. Evaluation of antitumor activity of Cuscuta reflexa Roxb (Cuscutaceae) against Ehrlich ascites carcinoma in swiss albino mice. Trop J Pharm Res 2011; 10 (4): 447454. http://dx.doi.org/10.4314/tjpr.v10i4.10

27. Jordan MA, Leslie W. Microtubules as a Target for Anticancer Drugs. Nature Reviews Cancer 2004; 4(4): 253-265. http://dx.doi .org/10.1038/nrc1317 PMid:15057285

28. Yang H, Ganguly A, Cabral F. Inhibition of Cell Migration and Cell Division Correlate with Distinct Effects of Microtubule Inhibiting Drugs. Journal of Biological Chemistry 2010; 285(42): 32242-32250. http://dx.doi.org/10.1074/jbc.M110.160820 PMCid:2952225

29. Fotsis T, Pepper MS, Aktas E, Breit S, Rasku S, Adler-creutz H. Flavonoid, dietary-derived inhibitors of cell proliferation and in vitro angiogenesis. Cancer Res 1997; 57: 2916-21. PMid:9230201

30. Zhao M, Yang B, Wang J, Liu Y, Yu L, Jiang Y. Immuno modulatory and anticancer activities of flavonoids extracted from litchi (Litchi chinensis Sonn) pericarp. Int Immunopharmacology 2007; 7: 162-66. http://dx.doi.org/10.1016/j.intimp.2006.09.003 PMid:17178382

31. Price VE, Greenfield RE. 'Anemia in cancer', in: J.P. Greenstein and A. Haddow (eds.). Advances in cancer research. vol V. New York: Academic Press; 1958. p. 199-200

32. Saha P, Mazumder UK, Haldar PK, Naskar S, Kundu S, Bala A et al. Anticancer activity of methanol extract of Cucurbita maxima against Ehrlich ascites carcinoma. Int J Res Pharm Sci 2011; 2(1): 52-59.

Cite this article as:

Sarkar Mahananda, Das Mousumi, Mitra Debmalya, Jena Aditya Kumar, De Arnab, Samanta Amalesh. Anticancer potential of methanolic and aqueous extract of Leucas indica (Linn.) against Ehrlich ascites carcinoma cells on Swiss albino mice. Int. Res. J. Pharm. 2013; 4(6):183-188 